\title{
THE REGIME OF THE WESTERN PART OF THE ROSS ICE SHELF DRAINAGE SYSTEM*
}

\author{
By M. Giovinetto,
}

(Geophysical and Polar Research Center, Department of Geology and Department of Geography, University of Wisconsin, Madison, Wisconsin, U.S.A.)

\section{EDwin S. Robinson} (Geophysical and Polar Research Center, University of Wisconsin, Madison, Wisconsin,
U.S.A.) $\dagger$

\author{
and C. W. M. Swithinbank \\ (Scott Polar Research Institute, Cambridge, England)
}

Abstract. The net mass budget is estimated for the western part of the Ross Ice Shelf drainage system. The area of the system is $(\mathrm{r} \cdot 75 \pm 0 \cdot 26) \times 10^{6} \mathrm{~km} .^{2}$, and the drainage periphery extends along the eastern flank of the Trans-Antarctic Mountains between lat. $77^{\circ} 5^{8^{\prime}} \mathrm{S}$., long. $164^{\circ} 37^{\prime} \mathrm{E}$. and lat. $85^{\circ} 27^{\prime} \mathrm{S}$. long. $^{\circ}$ $147^{\circ} 50^{\prime} \mathrm{W}$. Ice discharge is estimated from vertical cross-sections and corresponding ice-movement data for eight outlet glaciers. Free-air gravity anomalies, corrected for the effect of terrain above the glacier surface, are used to determine cross-sections of valleys by comparison with theoretical gravity profiles for several two-dimensional valley models. These data provide a basis for estimating the rate of ice discharge from the plateau, which is compared with the estimated rate of net accumulation at the surface, to determine the net budget of the ice sheet in the region. Representative mean rates of ice discharge measured in different types of glaciers are approximately $0.25 \times 10^{15} \mathrm{~g} . \mathrm{km}^{-1} \mathrm{yr} .^{-1}$ in outlet glaciers with large basins, and $0.05 \times 10^{15}$ g. $\mathrm{km}^{-1} \mathrm{yr}^{-1}$ in outlet glaciers with small basins. Taking into account the snowshed area and the rate of accumulation, the rate of ice discharge in cirque and piedmont glaciers is estimated at about $0.02 \times 10^{15}$ $\mathrm{g}$. $\mathrm{km}^{-1} \mathrm{yr}^{-1}$. The difference $\left(\left(4^{8} \pm 29\right) \times 10^{15} \mathrm{~g}^{\mathrm{yr}} \mathrm{yr}^{-1}\right)$ between mass input $\left(\left(9^{6} \pm 25\right) \times 10^{15} \mathrm{~g}^{\mathrm{yr}} \mathrm{y}^{-1}\right)$ and

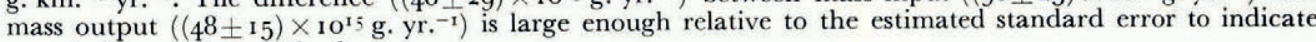
a probable positive net budget.

RÉsumÉ. Le régime du système de drainage de la partie ouest du Ross Ice Shelf. Le bilan de masse net est estimé pour le système de drainage de la partie ouest du Ross Ice Shelf. La surface de ce système est de $1,75 \pm 0,26 \times 10^{6} \mathrm{~km}^{2}$, et sa périphérie s'étend le long des flancs est des Trans-Antarctic Mountains entre $77^{\circ} 8^{\prime} \mathrm{S}, 164^{\circ} 37^{\prime} \mathrm{E}$ et $85^{\circ} 27^{\prime} \mathrm{S}, 147^{\circ} 50^{\prime} \mathrm{W}$. Le débit de glace est estimé à partir de sections droites verticales et les données correspondantes du mouvement pour huit glaciers effluents. Les anomalies gravimétriques à l'air libre, corrigées de l'effet topographique du terrain situé au-dessus de la surface des glaciers, ont été utilisées pour déterminer les sections droites des vallées par comparaison avec des profils gravimétriques théoriques pour plusieurs modèles bidimensionnels de vallée. Ces données forment une base pour l'estimation de la valeur du débit de la glace du plateau, débit comparé à la valeur estimée de l'accumulation nette à la surface, pour déterminer le bilan net de la couverture de glace de cette région. Les valeurs moyennes représentatives de débit de glace mesurées pour différents types de glaciers sont environ de $0,25 \times 10^{15}$ $\mathrm{g} \mathrm{km}^{-1}$ an ${ }^{-1}$ pour des glaciers effluents avec de grands bassins de drainage, et de $0,05 \times \mathrm{IO}^{15} \mathrm{~g} \mathrm{~km}^{-1} \mathrm{an}^{-1}$ pour des glaciers effluents avec de petits bassins de drainage. Tenant compte de la surface enneigée et de la valeur de l'accumulation, la valeur du débit de glace des glaciers de cirque et de piedmont est estimée à environ $0,02 \times 10^{15} \mathrm{~g} \mathrm{~km}^{-1} \mathrm{an}^{-1}$. La différence $48 \pm 29 \times 10^{15} \mathrm{~g} \mathrm{an}^{-1}$ entre l'apport de masse $96 \pm 25 \times 10^{15}$ $\mathrm{g} \mathrm{an^{-1 }}$ et la sortie de masse $48+15 \times 10^{15} \mathrm{~g}$ an ${ }^{-1}$, est assez large relativement à l'erreur standard estimée pour indiquer un bilan net positif probable.

Zusammenfassung. Der Massenhaushalt im Westteil des Einzugggebietes des Ross Ice Shelf. Für den Westteil des Einzugsgebietes des Ross Ice Shelf wird der Netto-Massenhaushalt abgeschätzt. Die Fläche des Gebietes beträgt $(1,75 \pm 0,26) \times 10^{6} \mathrm{~km}^{2}$; seine Grenze erstreckt sich längs der Ostflanke der Trans-Antarctic Mountains zwischen $77^{\circ} 5^{8}$ südl. Br., I6 $64^{\circ} 37^{\prime}$ östl. L. und $85^{\circ} 27^{\prime}$ südl. Br., I $47^{\circ} 55^{\prime}$ westl. L. Der Eisausstoss wird aus vertikalen Querprofilen und zugchörigen Fliessgeschwindigkeitswerten für acht Auslass-Gletscher abgeschätzt. Zur Bestimmung der Talquerschnitte werden Freiluftanomalien der Schwere, korrigiert um den Einfluss der Massen über der Gletscheroberfläche, benutzt; dabei werden theoretische Schwerkraftprofile für verschiedene zweidimensionale Talmodelle zum Vergleich herangezogen. Diese Daten ergeben eine Grundlage für die Abschätzung des Eisausstosses vom Polplateau, der mit der abgeschätzten NettoAkkumulation auf der Oberfläche verglichen wird, um den Netto-Haushalt des Inlandeises in diesem Gebiet zu bestimmen. Repräsentative Mittelwerte des Eisausstosses, gemessen an Gletschern verschiedenen Typs, sind ungefähr $0,25 \times 10^{15} \mathrm{~g} \mathrm{~km}^{-1}$ pro Jahr für Auslass-Gletscher mit grossem Becken und $0,05 \times 10^{15} \mathrm{~g} \mathrm{~km}^{-1}$ pro Jahr für Auslass-Gletscher mit kleinem Becken. Unter Berücksichtigung der Akkumulationsfläche und

* Geophysical and Polar Research Center, University of Wisconsin, Contribution No. I44.

$\uparrow$ Now at Department of Geophysics, College of Mines and Mineral Industries, University of Utah, Salt Lake City, Utah, U.S.A. 
-menge lässt sich der Eisausstoss in Kar- und Fussflächengletschern auf ca. $0,02 \times 10^{15} \mathrm{~g} \mathrm{~km}^{-1}$ pro $\mathrm{Jahr}$ abschätzen. Der Unterschied von $\left(4^{8} \pm 29\right) \times \mathrm{IO}^{15} \mathrm{~g}$ pro Jahr zwischen dem Auftrag von $(96 \pm 25) \times \mathrm{IO}^{15} \mathrm{~g}$ pro Jahr und dem Ausstoss von $(48 \pm 15) \times 10^{15} \mathrm{~g}$ pro Jahr ist im Verhältnis zu den abgeschätzten mittleren Fehlern gross genug um einen positiven Massenhaushalt als wahrscheinlich annehmen zu lassen.

\section{INTRODUCTION}

Between 1957 and 1963 various field parties have carried out glaciological studies in the western region of the Ross Ice Shelf drainage system (Fig. I), an area drained by glaciers feeding into the Ross Ice Shelf. Measurements of ice movement were made on the eight

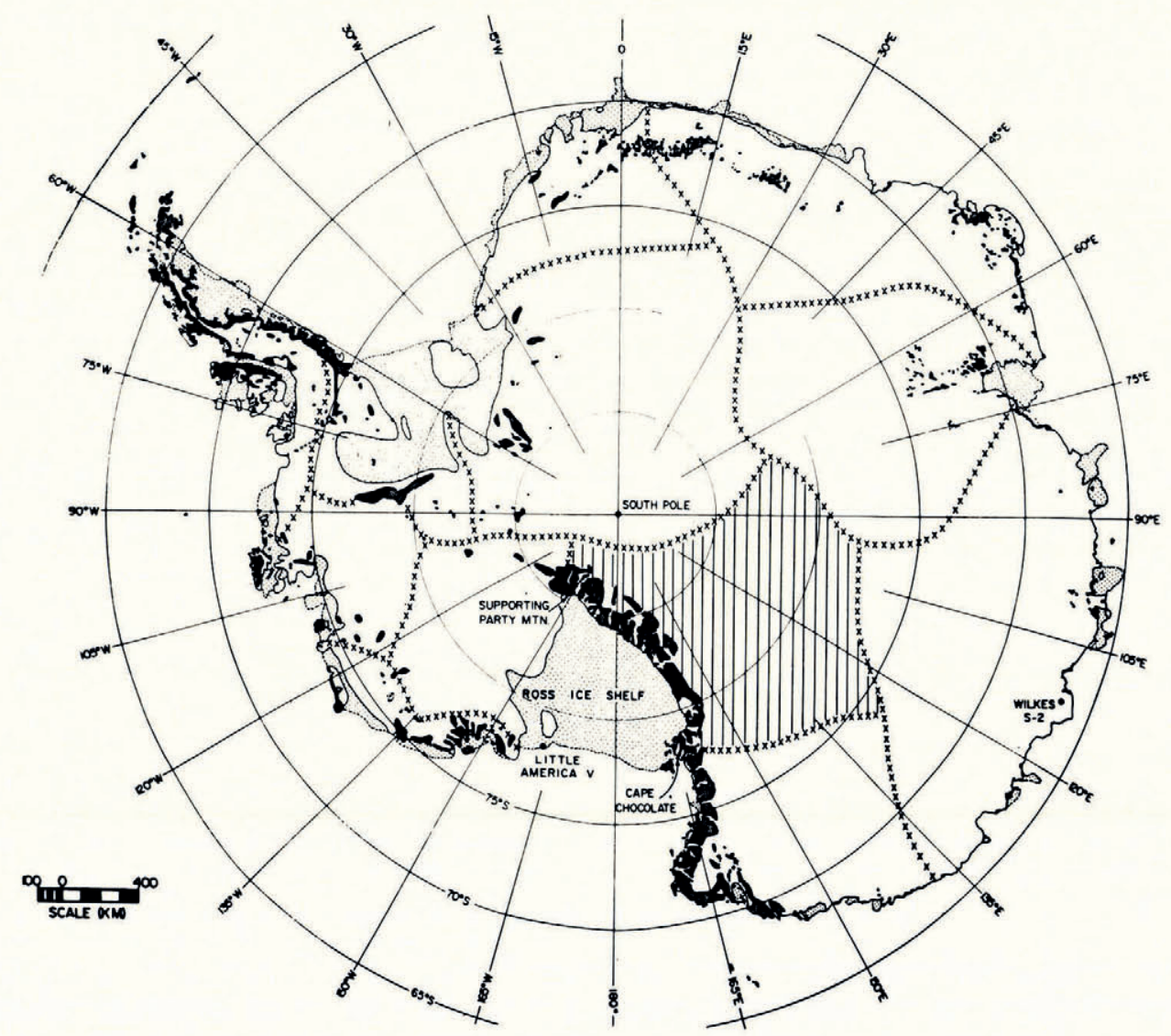

Fig. 1. The drainage divides in Antarctica (modified after Giovinetto $\left.\left(196_{4}[b]\right)\right)$ are shown with crosses. The area of the western part of the Ross Ice Shelf drainage system is vertically shaded. The drainage periphery extends from Cape Chocolate to Supporting Party Mountain

glaciers shown in Figure 2 in $195^{8}$ (Wilson and Crary, r 961 ) and in $1962-63$ (Swithinbank, I963), and gravity observations were made across the valleys to measure valley cross-sections. These data provide a basis for estimating the rate of ice discharge from the plateau, which is compared with the estimated rate of net accumulation at the surface to determine the net budget of the ice sheet in the region. The gravity analysis is treated in some detail, but accumulation values (Giovinetto, 1963) and ice-movement measurements (Swithinbank, ז963) have been described earlier and are only briefly reviewed. 


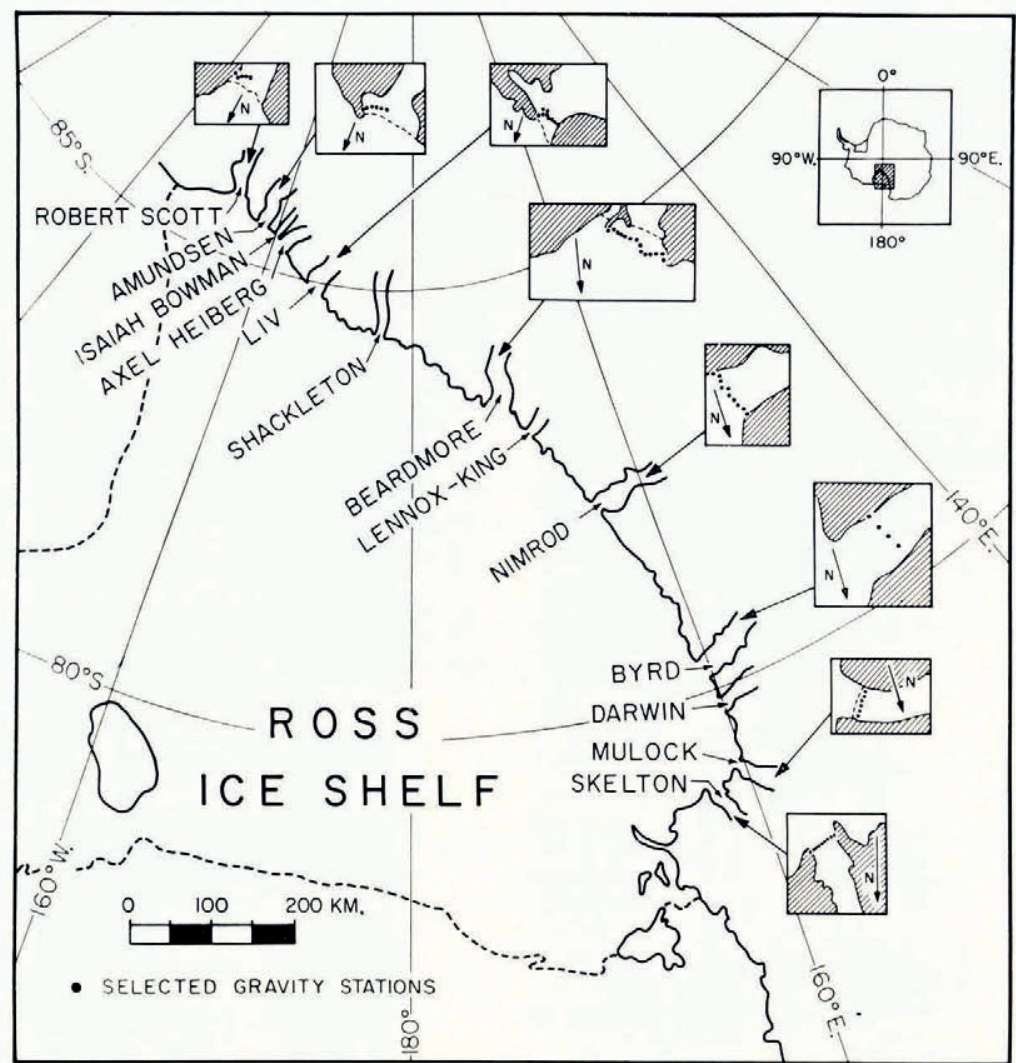

Fig. 2. Glaciers flowing into the Ross Ice Shelf upon which the gravity and ice-movement measurements were made

\section{Reduction of Gravity Data}

\section{The data}

Values of observed gravity accurate to \pm 2 mgal were obtained at 144 stations (Appendix) from readings of the Worden gravimeter No. 29 I adjusted to a base value of $982 \cdot 99^{2} \mathrm{gal}$ at the McMurdo pendulum station (lat. $77^{\circ} 53 \cdot$ I $^{\prime}$ S., long. $166^{\circ} 45 \cdot 3^{\prime}$ E.; I I m.; Fig. I). The station positions were established by triangulation measurements adjusted to control points from sun shots. Absolute elevations of several stations on the ice shelf were obtained by repeated aneroid altimeter ties with McMurdo station. Pressure corrections were determined from daily weather maps and barograph data. Because of the imprecise nature of the pressure maps and the great distance from the barograph station, it is difficult to estimate accurately the uncertainty in the absolute elevations. For the areas most distant from McMurdo station errors may exceed $\pm 50 \mathrm{~m}$. ; however, greater accuracy was realized for closer stations. Relative elevation differences across the glaciers were obtained with greater precision from theodolite and altimeter measurements referred to the glacier margins. These relative profiles were adjusted to the less precise sea-level datum values at ice-shelf stations. Table I gives estimates of the error in elevation for valley glaciers.

\section{Free-air anomalies}

Free-air anomalies were computed for all stations. The accuracy of these was estimated from the elevation error and the constant $0.3086 \mathrm{mgal} \mathrm{m} .^{-1}$. Values of observed gravity, station positions and elevations, and free-air anomalies are tabulated in the Appendix. 


\section{Computation of Valley Cross-Sections}

\section{The method}

Valley cross-sections for the glaciers were computed from free-air anomalies corrected for the effect of terrain above the glacier surface (Appendix). Terrain corrections were computed by the line integral method (Hubbert, 1948) from cross-sectional sketches of valley sides made in the field. The estimated uncertainty of about 20 per cent in these corrections results from

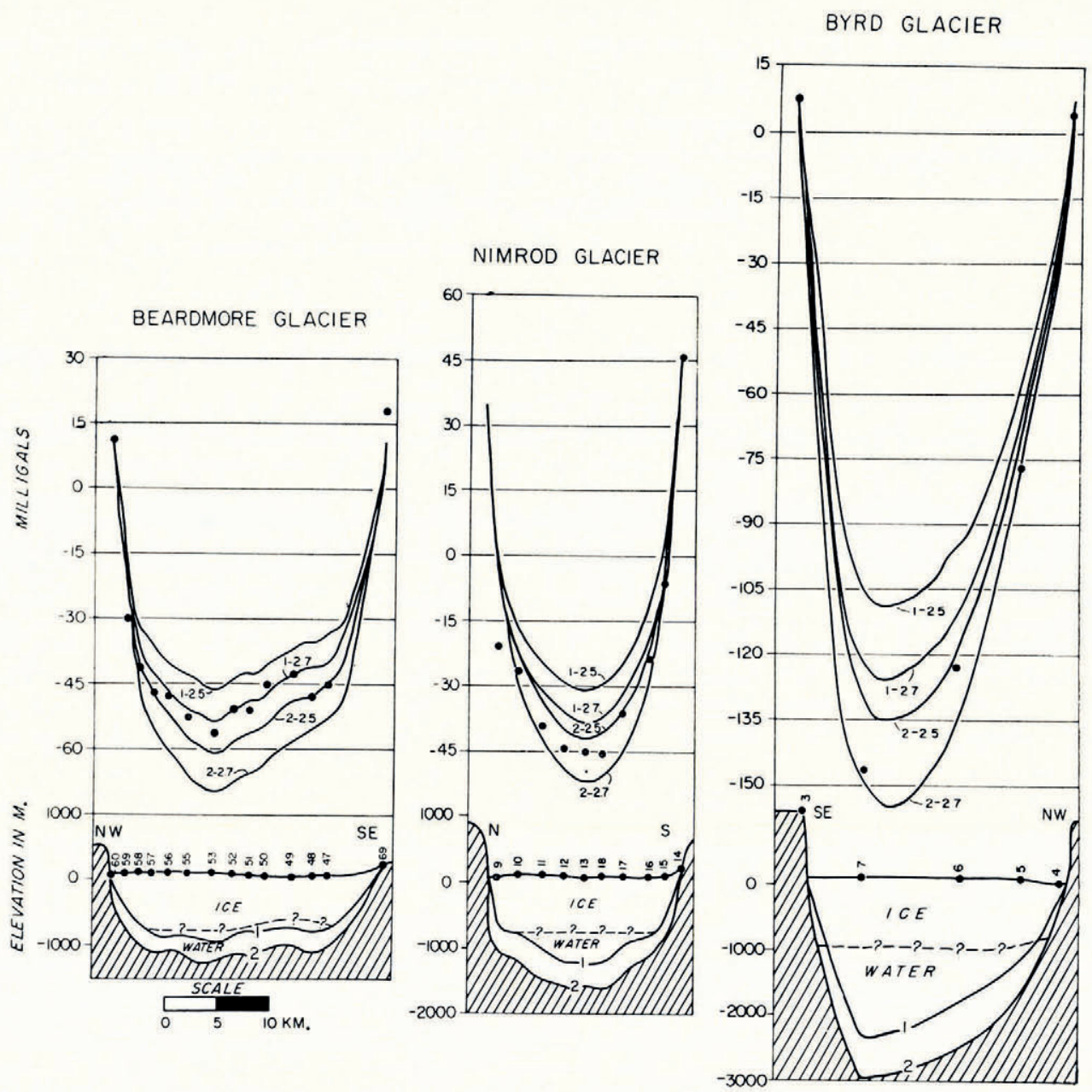

Fig. 3. Valley cross-sections and corresponding gravity profiles for floating glaciers

imprecise topographic and rock-density information. The free-air anomaly profile was assumed to be a function of subglacial rock-surface relief, which is a justifiable first approximation, because the density difference between ice (or water) and rock is much larger than contrasts between deeper rock units. Since it is reasonable to expect the average density to lie between 2.5 and 2.7 g. cm. ${ }^{-3}$, probable limits for subglacial rock elevation were established by computing theoretical gravity profiles for several two-dimensional valley models assigned these densities. Computations were made using the line integral approximation described by Talwani and others (1959). 
Valley cross-sections

Figures 3 and 4 show two cross-sections for each valley and the corresponding gravity profiles compared with observed data. To show the possible effects due to the presence of lowdensity rock, calculations for Liv Glacier included an additional rock-elevation profile and an additional density value of $2 \cdot 0 \mathrm{~g} . \mathrm{cm} .^{-3}$. The computed gravity profiles were tied to the observed anomalies at the glacier margins. Since these profiles include most of the free-air anomalies, the cross-sections indicate the range within which true rock elevations lie. It is
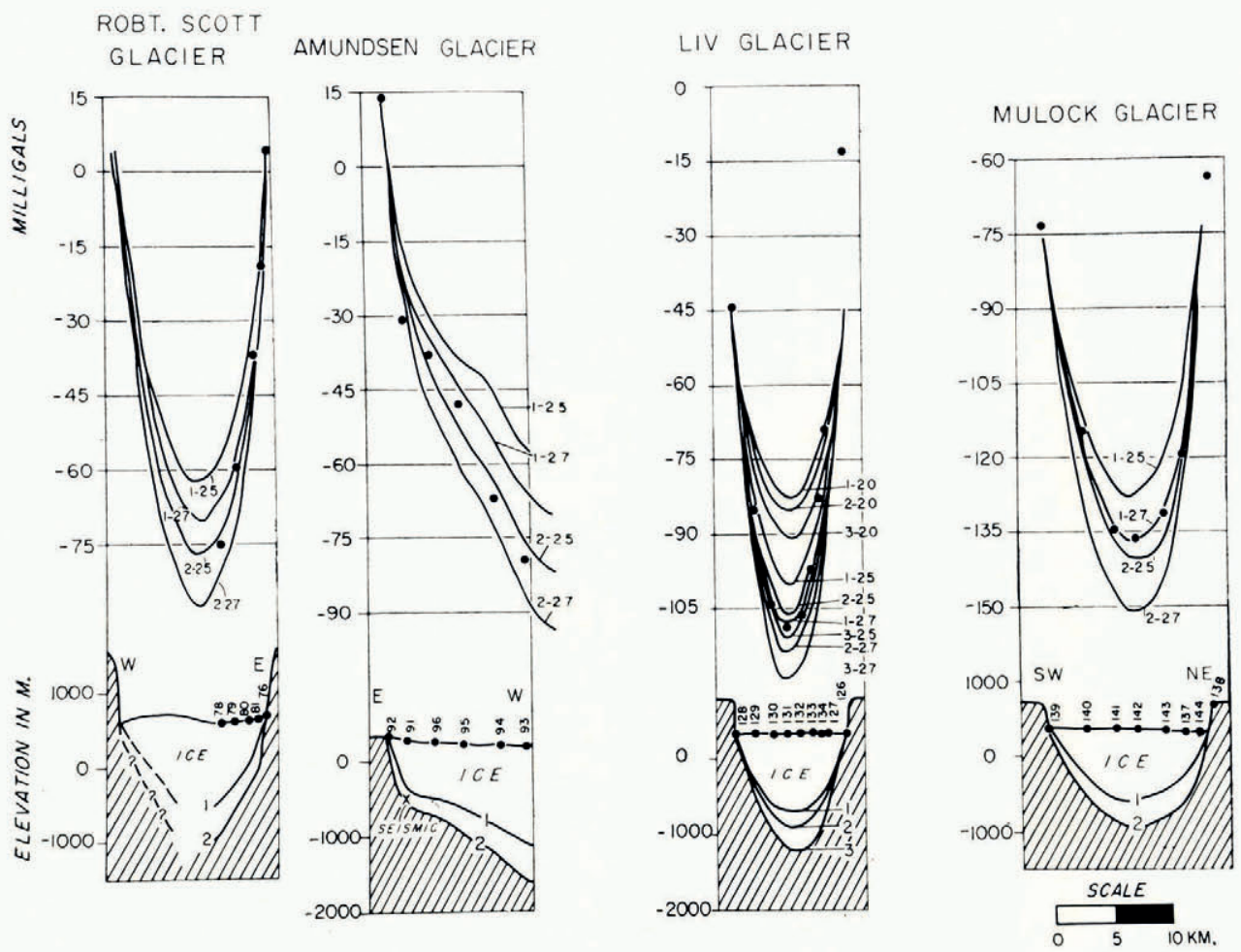

Fig. 4. Valley cross-sections and corresponding gravity profiles for grounded glaciers

not justifiable to assume a narrower density range, and therefore it is not possible to estimate the elevation of the rock surface more precisely. A few observed values are not enclosed by the theoretical profiles; they probably result from the regional gravity anomaly along the western margin of the Ross Ice Shelf (Robinson, unpublished). Because the gravity meter measures change in a potential field gradient caused by nearby relief as well as that immediately beneath it, the analysis gives smoothed valley cross-sections with minimal indication of local subglacial features. The reliability of ice-thickness values (or valley depths where the glaciers are afloat; Fig. 3) determined from gravity data is assessed using data obtained by seismicreflection measurements. One seismic measurement near the margin of Amundsen Glacier indicates a true rock elevation between the two profiles assumed for gravity calculations. The reliability of this method of computing valley cross-sections can be further considered by examining data from Skelton Glacier (Wilson and Crary, 196r). Figure 5 shows a valley cross-section for the line of observation points given in Figure 2. Seismic-reflection measurements were made at seven sites, and corresponding free-air anomalies were obtained at these 
and two additional points. Four theoretical gravity profiles were computed for this crosssection for assumed average rock densities of $2 \cdot 3,2 \cdot 4,2 \cdot 5$ and $2 \cdot 7 \mathrm{~g} . \mathrm{cm}^{-3}$. These relative profiles were adjusted to observed free-air anomalies at the two most widely separated seismic sites: stations 6r.2 and 6r.6 (see circled points in Figure 5). The comparison of these profiles with observed anomalies at intermediate sites indicates that average rock density for the lower central part of the valley is between 2.3 and $2.4 \mathrm{~g}$. $\mathrm{cm} .^{-3}$. Rock elevation was not precisely known near the glacier margins (sites $6 \mathrm{r} .7$ and $6 \mathrm{r} .8$ ), and an estimate of the average density along the steeper slopes near the sides of the valley cannot be obtained. It is reasonable to

\section{SKELTON GLACIER}

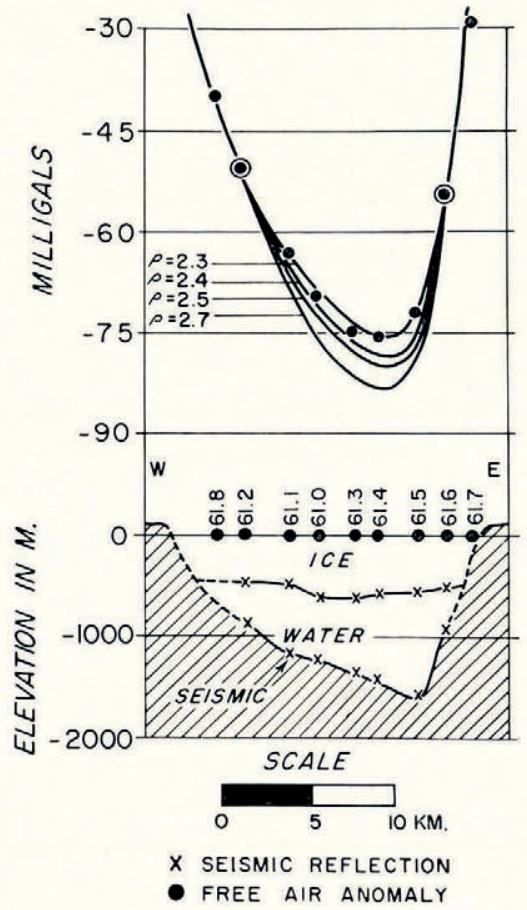

Fig. 5. Valley cross-section and corresponding gravity profiles for Skelton Glacier

expect a higher average density since a thinner low-density moraine would be expected on the steep slopes than in the center of the valley. Hence, there is justification in assuming a higher average density when calculating valley cross-sections from gravity profiles adjusted to observed values at the margins.

\section{Measured Ice Discharge}

Areas of vertical cross-sections of ice, computed from the valley models, are given in Table I. The ice thickness of floating glaciers was calculated from surface elevation. Possible elevation error for floating ice and the two limiting profiles of rock elevation for the grounded ice are the basis for the estimates of uncertainty. To obtain the estimates of rates of ice discharge (Table I), values of average surface velocity, computed from triangulation measurements of stakes on glacier surfaces by Swithinbank (1963), were used with areas of crosssections. The area of the western half of the cross-section of Amundsen Glacier was estimated 
by extrapolation; the probable error is about 50 per cent. Table I also includes data of Wilson and Crary (196r) for Skelton Glacier.

Table I. Accuracy of Elevation Measurements Used in the Reduction of Gravity Data, and Estimated Errors in the Measurements of Ice Discharge

\section{Glacier}

Robert Scott Glacier

Amundsen Glacier

Liv Glacier

Beardmore Glacier

Nimrod Glacier

Byrd Glacier

Mulock Glacier

Skelton Glacier $\uparrow$

Measured discharge (total)

Error in elevation
Relative to
sea-level
glacier margin

$\mathrm{m}$

$$
\pm 30
$$$$
\pm 30
$$

$\pm 30$

$\pm 10$

$\pm \mathrm{IO}$

$\pm 5^{\circ}$

$\pm 15$

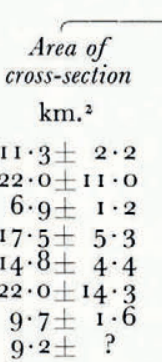

-Ice discharge

Mean surface velocity*

km. yr. ${ }^{-1}$

$\mathrm{o} \cdot 18 \pm 0 \cdot 0 \mathrm{I}$

$0 \cdot 15 \pm 0 \cdot 01$

$0.07 \pm 0.01$

$0 \cdot 33 \pm$ -

$0.15 \pm-$
$0.74 \pm 0.01$

$0 \cdot 29 \pm$ ?
$0 \cdot 09 \pm$ ?
Ice output

$\mathrm{km} \cdot{ }^{3} \mathrm{yr}^{-\mathrm{t}}$

$2 \cdot 0 \pm 0 \cdot 4$

$3 \cdot 3 \pm 1 \cdot 7$

$0 \cdot 5 \pm 0 \cdot 1$

$5 \cdot 8 \pm 1 \cdot 7$

$2 \cdot 2 \pm 0 \cdot 7$

$16 \cdot 3 \pm 10 \cdot 6$

$2 \cdot 8 \pm 0.5$

$0 \cdot 8 \pm$ ?

$33 \cdot 7 \pm 10 \cdot 9$

* After Swithinbank (1963).

$\dagger$ Wilson and Crary (196i).

In the sections where movement was measured on Beardmore, Nimrod, Byrd and Skelton Glaciers, the ice was afloat. Although surface velocity is probably representative of average velocity for floating ice, this is not true for grounded ice. Nothing is known about longitudinal slope or bed roughness for the glaciers, and so the average velocity for grounded glaciers cannot be estimated; therefore, the estimates of discharge represent upper limits. The total ice discharge through the eight glaciers is $33 \cdot 7 \pm 10 \cdot 9 \mathrm{~km} \cdot{ }^{3} \mathrm{yr}^{-1}$, or approximately $(30 \pm 7) \times \mathrm{IO}^{15}$ g. $\mathrm{yr}^{-\mathrm{I}}$, using a mean density of $0.9 \mathrm{~g} . \mathrm{cm}^{-3}$ for the ice and firn. In the determination the individual errors for ice discharge were treated as standard errors. Unless otherwise specified, all errors are expressed as standard errors.

\section{The Regime and the Mass Budget}

The net mass budget for the western part of the Ross Ice Shelf drainage system is the difference between the rate of net mass accumulation at the surface and the rate of mass output at the drainage periphery. The drainage periphery is the boundary of grounded ice lying between Cape Chocolate (lat. $77^{\circ} 5^{8^{\prime}}$ S., long. $164^{\circ} 37^{\prime}$ E.) and the north-western extremity of Supporting Party Mountain (approximately lat. $85^{\circ} 27^{\prime}$ S., long. $147^{\circ} 50^{\prime}$ W.).

\section{Net Mass Acqumulation at the Surface}

Taking into account the area of net ablation at the surface in regions where surface slope favors snow deflation and a composite error due to uncertainties in the determination of mean accumulation ( 2 I per cent) and area ( 15 per cent) for the whole Ross Ice Shelf drainage system (Giovinetto, I964[a]), the rate of total accumulation for the drainage system is estimated to be $(96 \pm 25) \times 10^{15} \mathrm{~g}$. yr. ${ }^{-1}$. The mean accumulation is $5 \cdot 5 \pm \mathrm{I} \cdot 2 \mathrm{~g} . \mathrm{cm} \cdot .^{-2} \mathrm{yr}^{-1}$, and the area is $(\mathrm{r} \cdot 75 \pm 0 \cdot 26) \times \mathrm{IO}^{6} \mathrm{~km}^{2}$ (Giovinetto, $\left.\mathrm{I}_{96} 6[\mathrm{~b}]\right)$. The mean accumulation data selected for particular locations are those obtained using two different methods (Crary, I963; Giovinetto, 1963). These values were selected in preference to greater mean values for particular locations which were reported in earlier studies (Lister, i960).

\section{Mass Output at the Drainage Periphery}

Glacier width

For purposes of extrapolating values of ice discharge the combined widths have been estimated at the drainage periphery of glaciers classified into four categories. The estimates were made from the chart of Antarctica ( $1: 3,000,000$; 1962 ) compiled by the American 
Geographical Society, supplemented by recent aerophotographic material (Seelig, I964; Swithinbank, 1964). Examination of photographs indicates that estimates based upon the chart alone would be about i 5 per cent too large. The four glacier categories are described below and the combined widths of glaciers in each are given. (i) Outlet glaciers draining large inland basins are Robert Scott, Amundsen, Shackleton, Beardmore, Nimrod, Byrd and Mulock Glaciers (Swithinbank, I964). They have a combined width of $125 \mathrm{~km}$. at the drainage periphery. (ii) Outlet glaciers draining small inland basins are Isaiah Bowman, Axel Heiberg, Liv, Lennox-King, Darwin and Skelton Glaciers with a combined width of $80 \mathrm{~km}$. (Fig. 2). (iii) Thirteen glaciers are classified as "cirque" glaciers in this discussion. These glaciers drain regions limited by the drainage periphery and the main ridge of the Trans-Antarctic Mountains which are not drained by tributaries to the outlet glaciers. Their combined width is $140 \mathrm{~km}$. (iv) "Piedmont" glaciers flowing eastward from the main ridge of the Trans-Antarctic Mountains principally between lat. $80^{\circ} 45^{\prime}$ and $82^{\circ} \mathrm{Io}^{\prime} \mathrm{S}$. have a combined width of $250 \mathrm{~km}$.

The error in the estimate of total width of the glaciers is approximately ro per cent, although it is greater for individual glaciers where mapping is inadequate. Nine relatively small cirque glaciers with a total width of $40 \mathrm{~km}$. are shown in the American Geographical Society's chart. They were excluded from this study because their topography inland is totally unknown; according to the chart they intersect the drainage periphery at approximately lat. $88^{\circ} 50^{\prime} \mathrm{S}$. (one), $83^{\circ} \mathrm{S}$. (two), $83^{\circ} 25^{\prime} \mathrm{S}$. (one), and between lat. $84^{\circ} 30^{\prime}$ and $84^{\circ} 50^{\prime} \mathrm{S}$. (five).

\section{Mass output in outlet glaciers (large basins)}

The glaciers listed in Table I (with exception of Liv and Skelton Glaciers) are representative of outlet glaciers draining large basins. The extrapolated value of ice discharge based on the total width of all outlet glaciers is $35.4 \pm 10.9 \mathrm{~km} .{ }^{3} \mathrm{yr}^{-1}$ or $\left(3^{2} \pm 10\right) \times 10^{15} \mathrm{~g} . \mathrm{yr} .^{-1}$. The rate of ice discharge for Shackleton Glacier is estimated to be $3.0 \pm 0.6 \mathrm{~km} .^{3} \mathrm{yr}^{-1}$, assuming a mean ice discharge for the outlet glaciers of $0.19 \pm 0.4 \mathrm{~km} .{ }^{3} \mathrm{~km} \cdot{ }^{-1} \mathrm{yr} .^{-1}$. The mean ice discharge per kilometer and the error for Shackleton Glacier are estimated using the smaller of the two magnitudes of ice discharge evident in Table I. The mean for Robert Scott, Amundsen, Beardmore, Nimrod and Mulock Glaciers is approximately $0 \cdot 19 \mathrm{~km} .{ }^{3} \mathrm{~km} \cdot{ }^{-1} \mathrm{yr} .^{-1}$. The mean for Byrd Glacier is approximately $0.68 \mathrm{~km} \cdot{ }^{3} \mathrm{~km} \cdot{ }^{-1} \mathrm{yr}^{-1}$.

\section{Mass output in outlet glaciers (small basins)}

Using the data from Liv and Skelton Glaciers, the mean ice discharge for outlet glaciers draining relatively small basins is estimated to be approximately $0 \cdot 05 \pm 0 \cdot 02 \mathrm{~km} \cdot{ }^{3} \mathrm{~km} .^{-1} \mathrm{yr}^{-1}$ (the error of $3^{8}$ per cent is estimated simply by doubling the error computed for ice discharge in Liv Glacier). Hence, their contribution to the ice shelf is $4 \cdot 0 \pm \mathrm{I} \cdot 5 \mathrm{~km} \cdot{ }^{3} \mathrm{yr}^{-1}$ or $(4 \pm \mathrm{I}) \times 10^{15} \mathrm{~g} \cdot \mathrm{yr}^{-1}$.

\section{Mass output in "cirque" and "piedmont" glaciers}

No measurements of ice discharge have been made on cirque and piedmont glaciers, but the rate of mass output can be estimated from the snowshed area and the corresponding rate of accumulation. The drainage periphery is approximately $\mathrm{I}, \mathrm{I} 00 \mathrm{~km}$. long, and includes $205 \mathrm{~km}$. of outlet glaciers, $250 \mathrm{~km}$. of piedmont glaciers, and $140 \mathrm{~km}$. of cirque glaciers. The remaining $500 \mathrm{~km}$. correspond to the perimeter of narrow capes and peninsulas where mass movement is parallel to the drainage periphery, tributary glaciers feeding into outlet and cirque glaciers. These tributary glaciers are of three main types, i.e. valley, cirque and hanging glaciers.

The piedmont glaciers flow eastward on the flanks of the Trans-Antarctic Mountains, principally between lat. $80^{\circ} 45^{\prime}$ and $82^{\circ}$ I $0^{\prime} \mathrm{S}$. They drain an area which extends directly inland from the drainage periphery to the main ridge of the Trans-Antarctic Mountains; these 
lie, in general, between $5^{\circ}$ and $100 \mathrm{~km}$. from each other. Hence the combined snowshed area of $19,000 \pm 6,000 \mathrm{~km} .^{2}$ is obtained from the periphery width of $250 \mathrm{~km}$. and the inland extent of $75 \pm 25 \mathrm{~km}$. The estimated mean net accumulation of $25 \pm 5 \mathrm{~g} . \mathrm{cm}^{-2} \mathrm{yr}^{-1}$ (Giovinetto, $1963,1964[\mathrm{a}])$ and the assumption that the piedmont glaciers are in a situation of steadystate determine the total mass output to be $(5 \pm 2) \times 10^{15} \mathrm{~g} . \mathrm{cm}^{-2} \mathrm{yr}^{-1}$.

The remaining $850 \mathrm{~km}$. of the drainage periphery and the main ridge of the TransAntarctic Mountains $\left(75 \pm 25 \mathrm{~km}\right.$. apart) limit an area of $64,000 \pm 21,000 \mathrm{~km} .{ }^{2}$. Here tributary glaciers drain into outlet and cirque glaciers. Such a discharge into outlet glaciers has already been accounted for; it remains to estimate the ice discharge by tributary glaciers into cirque glaciers. It is assumed that from the combined snowshed area of $64,000 \pm 28,000 \mathrm{~km} .^{2}$ the area of regions drained through tributaries by cirque and outlet glaciers is proportional to the width of these glaciers at the drainage periphery ( 140 and $205 \mathrm{~km}$., respectively). Hence the total area drained by cirque glaciers is $26,000 \pm 9,000 \mathrm{~km} .{ }^{2}$. Using the estimated mean net accumulation of $25 \pm 5 \mathrm{~g} . \mathrm{cm}^{-2} \mathrm{yr}^{-1}$ and assuming a situation of steady-state, the rate of mass output is $(7 \pm 2) \times 10^{15} \mathrm{~g} \cdot \mathrm{yr}^{-1}$.

\section{Total mass output}

The loss of mass by surface ablation in outlet and cirque glaciers is negligible relative to the amount of total ice discharge, and has been accounted for in estimating net accumulation at the surface. The mass loss by oceanic melting from the four glaciers where the drainage periphery lies in floating sections is also negligible because: (i) Beardmore Glacier is grounded a few kilometers up-stream from the section where ice movement was measured. (ii) The remaining three glaciers, with a total width of only $55 \mathrm{~km}$. are probably grounded inland from the main ridge of the Trans-Antarctic Mountains. If the rate of bottom melting in these glaciers is one-half the rate estimated by Crary (1964) for "Little America V" (Fig. I), i.e. $30 \mathrm{~g} . \mathrm{cm} \cdot{ }^{-2} \mathrm{yr}^{-1}$, mass loss by oceanic melting is about $10^{15} \mathrm{~g} \cdot \mathrm{yr}^{-1}$. This value was neglected as it would not change the estimates of ice discharge by outlet and cirque glaciers at the drainage periphery (grounded ice).

From the factors given, the total mass flux at the $1,100 \mathrm{~km}$. long periphery is estimated to be $\left(48 \pm{ }^{15}\right) \times$ IO $^{15} \mathrm{~g} \mathrm{yr}^{-1}$.

\section{Mass flux}

Despite the relatively low rate of mass output, exceptionally high rates of ice movement in some of the outlet glaciers and correspondingly great mass flux occur (Swithinbank, 1964), caused by the damming effect of the Trans-Antarctic Mountains. Mean mass flux at the drainage periphery is estimated at $(0.04 \pm 0 \cdot 0 \mathrm{I}) \times 1 \mathrm{IO}^{15} \mathrm{~g} . \mathrm{km}^{-1} \mathrm{yr}^{-1}$; this rate is relatively low compared with the mean mass flux for the periphery of the grounded ice sheet in Antarctica $\left((0 \cdot 9 \pm 0 \cdot 5) \times \mathrm{IO}^{15} \mathrm{~g} . \mathrm{km}^{-1} \mathrm{yr}^{-1}\right.$; Giovinetto, $\left.1964[\mathrm{~b}]\right)$. From the discussion on estimating values of ice discharge for different types of glaciers the following mean values of mass flux are deduced: mass flux in outlet glaciers with large drainage basins is approximately $0.25 \times 10^{15}$ g. $\mathrm{km} .^{-1} \mathrm{yr}^{-1}$; in outlet glaciers with small basins and cirque glaciers it is $0.05 \times 10^{15}$ g. $\mathrm{km} .^{-1} \mathrm{yr}^{-1}$; and in piedmont glaciers it is $0 \cdot 02 \times 10^{15} \mathrm{~g} . \mathrm{km}^{-1} \mathrm{yr}^{-1}$. The values of mass flux at the grounded (or close to grounded) periphery sections of single glaciers listed in Table I range from less than $0.02 \times 10^{15}$ to $0.68 \times 10^{15} \mathrm{~g} . \mathrm{km} .^{-1} \mathrm{yr}^{-1}$. Factors greater than 30 between mean values of mass flux for single glaciers and greater than ro between mean values for particular glacier types demonstrate the physiographic complexity of the drainage periphery.

\section{Net Budget}

The difference between the estimates of mass input $\left((96 \pm 25) \times 10^{15} \mathrm{~g}\right.$. yr. $\left.{ }^{-1}\right)$ and mass output $\left(\left(4^{8} \pm \mathrm{I}_{5}\right) \times \mathrm{IO}^{\mathrm{I} 5} \mathrm{~g}\right.$. $\left.\mathrm{yr}^{-1}\right)$ suggests a positive net budget $\left(\left(4^{8} \pm 29\right) \times \mathrm{IO}^{\mathrm{I} 5} \mathrm{~g} . \mathrm{yr}^{-1}\right)$. 
It would be unrealistic to make a rigorous significance test on the net budget estimate because the "mean" values of mass input and output are estimates based on sets of heterogeneous data, and the standard errors are estimates themselves. Nevertheless, the net budget estimate is $\mathrm{I} \cdot 7$ times the standard error, including a large probability that the net budget is different from zero.

\section{Concluding Remarks}

The preceding discussion, stressing the errors in all estimates and the magnitude of the standard error, shows that a net budget of $5^{\circ}$ per cent is not significant. This has been stated before regarding Antarctic drainage systems (Giovinetto, I964[a]).

The present estimate of the net budget might be questioned, because the data cover periods of $2 \mathrm{yr}$. (mass output) and $5 \mathrm{yr}$. (mass input). The temporal variability of the rate of mass output is unknown, but it is reasonable to assume that it would be less variable than the rate of mass input which can be estimated. The variability of the rate of precipitation decreases as the area for which the variability is estimated increases (e.g. Schwerdtfeger, I95I). A correlation study of accumulation data for periods longer than ioo yr. at three stations shown in Figure I, i.e. South Pole (Giovinetto, I 96o), Wilkes S-2 (Cameron and others, I959; Fig. I) and "Little America V" (Gow, 1963) indicates that the variability of ro yr. means of net accumulation at the surface for comparable areas is approximately 2 per cent (personal communication from W. Schwerdtfeger) or 3 per cent for $5 \mathrm{yr}$. means. Evidently the difference between the rates of mass input and mass output cannot be caused completely by their variability.

There is no evidence of a significant secular change in the rates of mass input and output which would justify re-estimating the net budget. Approximately one-half the amount of the total mass input corresponds to a $200 \mathrm{~km}$. wide zone adjacent to the drainage periphery (Giovinetto, 1963). A significant change in the rate of mass input should be detectable as a change in the rate of mass output after a few decades, certainly less than roo yr. (e.g. Weertman, I958). However, in a study of the significant increase in the rate of accumulation at the South Pole between I760 and 1957 (Giovinetto and Schwerdtfeger, I966), it is shown that there were no significant changes in the rate of accumulation for comparable periods at "Little America V" and Wilkes S-2 (Fig. I). Hence there is evidence to support a secular increase in the rate of accumulation only in the southern part of the system where accumulation is small.

\section{AcKnowledgements}

The field work and data analysis were supported by grants from the National Science Foundation to the University of Michigan and the University of Wisconsin. Logistics support was provided by the U.S. Navy. Individuals whose help in field work or in data reduction made this work possible are: D. G. Darby, E. Dorrer, D. Lavin, O. Liestøl, H. W. Linder, J. J. Olson, A. S. Rundle, T. E. Taylor, E. Thiel (deceased) and J. Tuck. It is a pleasure to acknowledge the critical review of the manuscript by C. R. Bentley, K. W. Butzer and W. Schwerdtfeger.

MS. received 3 March 1965

\section{REFERENCES}

Cameron, R. L., and others. 1960. Wilkes station glaciological data, by R. L. Cameron, O. H. Løken and J. R. T. Molholm. Ohio State University Research Foundation. Report $825^{-1}-$ III.

Crary, A. P. 1963. Results of United States traverses in East Antarctica, 1958-1961. IG Y Glaciological Report (New York), No. 7 .

Crary, A. P. 1964. Melting at the ice-water interface, "Little America" station. Journal of Glaciology, Vol. 5, No. 37, p. $129-30$. [Letter.] 
Giovinetto, M. B. 1960. Glaciology report for 1958, South Pole station. Ohio State University Research Foundation. Report $825-2-\mathrm{IV}$.

Giovinetto, M. B. 1963. Glaciological studies on the McMurdo-South Pole traverse, 196o-6r. Ohio State University. Institute of Polar Studies. Report No. 7 .

Giovinetto, M. B. $1964[\mathrm{a}]$. The drainage systems of Antarctica: accumulation. (In Mellor, M., ed. Antarctic snow and ice studies. Washington, D.C., American Geophysical Union, p. 127-55. (Antarctic Research Series, Vol. 2.))

Giovinetto, M. B. 1964[b]. An estimate of mass flux, Antarctica. Geological Society of America. Special Papers, No. 76, p. 309. [Abstract.]

Giovinetto, M. B., and Schwerdtfeger, W. 1966. Analysis of a 200-year snow accumulation series from the South Pole. Archiv für Meteorologie, Geophysik und Bioklimatologie, Ser. A, Bd. 15, Ht. 2. [In press, January 1966.]

Gow, A. J. 1963. The inner structure of the Ross Ice Shelf at Little America V, Antarctica, as revealed by deep core drilling. Union Géodésique et Géophysique Internationale. Association Internationale d'Hydrologie Scientifique. Assemblée générale de Berkeley, 19-8-31-8 1963. Commission des Neiges et des Glaces, p. 272-84.

Hubbert, M. K. 1948. A line integral method of computing the gravimetric effects of two-dimensional masses. Geophysics, Vol. 13, No. 2, p. 215-25.

Lister, H. 1960. Glaciology. I. Solid precipitation and drift snow. Trans-Antarctic Expedition, 1955-1958. Scientific Reports, No. 5 .

Robinson, E. S. Unpublished. Geological structure of the Transantarctic Mountains and adjacent ice covered areas, Antarctica. [Ph.D. thesis, University of Wisconsin, I964.]

Schwerdtfeger, W. I95I. Gedanken über ein Ausgleichsprinzip des atmosphärischen Gesamt-Niederschlags. Meteorologische Rundschau, Bd. 4, Ht. 5/6, p. 96-97.

Seelig, W. R. 1964. Topographic mapping of Antarctica. Antarctic Report (Washington, D.C.), June I964, p. 2-18.

Swithinbank, C. W. M. I963. Ice movement of valley glaciers flowing into the Ross Ice Shelf, Antarctica. Science, Vol. 141, No. 3580 , p. 523-24.

Swithinbank, C. W. M. I964. The valley glaciers that feed the Ross Ice Shelf. Polar Record, Vol. 12, No. 76, p. $80-82$.

Talwani, M., and others. 1959. Rapid gravity computations for two-dimensional bodies with application to the Mendocino submarine fracture zone, by M. Talwani, J. L. Worzel and M. Landisman. Fournal of Geophysical Research, Vol. 64, No. I, p. 49-6o.

Weertman, J. I958. Traveling waves on glaciers. Union Géodésique et Géophysique Internationale. Association Internationale d'Hydrologie Scientifique. Symposium de Chamonix, I6-24 sept. 1958, p. I62-68.

Wilson, C. R., and Crary, A. P. 196r. Ice movement studies on the Skelton Glacier. Fournal of Glaciology, Vol. 3, No. 29 , p. $873-78$.

\section{APPENDIX}

Gravity Values: 1961-62 Ross Ice Shelf Glaciology Traverse

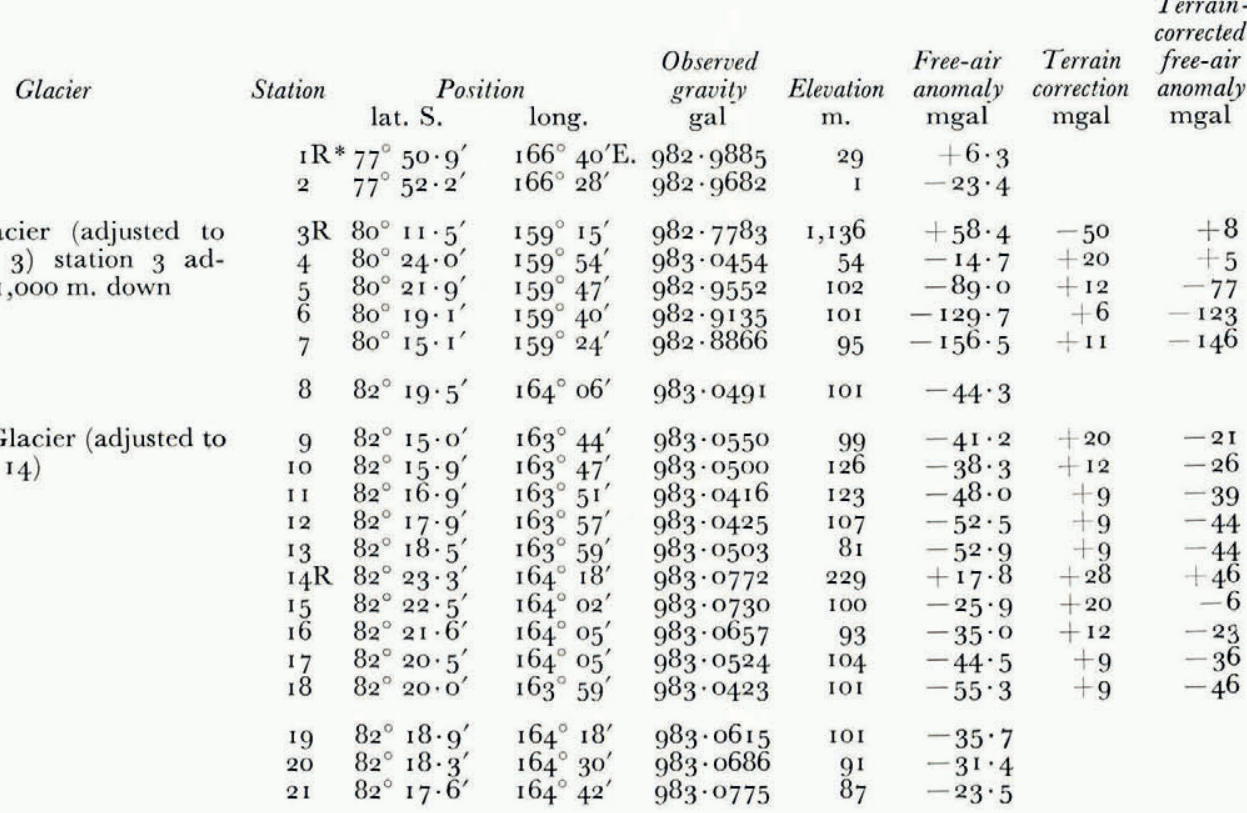

Byrd Glacier (adjusted to station 3) station 3 adjusted I, ooo m. down

Nimrod Glacier (adjusted to station 14)

* The symbol " $\mathrm{R}$ " designates gravity stations on outcropping rock. 
Beardmore Glacier (adjusted to stations 60 and 69)

Beardmore Glacier

Robert Scott Glacier (adjusted to station 76 )

Station

22
23
24
25
26
27
28
29
30
31
32
33
34
35
36
37
38
39
40
41
42
43
44
45
46

Position lat. S. long.

$82^{\circ} 16 \cdot 7^{\prime}$ $82^{\circ} 15 \cdot 3^{\prime}$ $82^{\circ} 13.9^{\prime}$ $82^{\circ} 12 \cdot 5^{\prime}$ $82^{\circ} \mathrm{I} \cdot \mathrm{O}^{\prime}$ $82^{\circ}$ o9. $6^{\prime}$ $82^{\circ} \mathrm{o} \cdot 8^{\circ}$ $82^{\circ} 07 \cdot 2^{\prime}$ $82^{\circ} 07 \cdot 4^{\prime}$ $82^{\circ} 07 \cdot 7^{\prime}$ $82^{\circ}$ o8.2 $82^{\circ} 08 \cdot 4^{\prime}$ $82^{\circ} 22 \cdot 2^{\prime}$ $82^{\circ} 34 \cdot 3^{\prime}$ $82^{\circ} 38 \cdot 8^{\prime}$ $82^{\circ} 44 \cdot 8^{\prime}$ $82^{\circ} 48 \cdot 6^{\prime}$ $82^{\circ} 53.3^{\prime}$ $82^{\circ} 58 \cdot 0^{\prime}$ $83^{\circ} \mathrm{0} 3 \cdot 3^{\prime}$ $83^{\circ} \mathrm{0} 7 \cdot 3$ $83^{\circ} 13 \cdot 2^{\prime}$ $83^{\circ} 17 \cdot 7^{\prime}$ $83^{\circ} 20 \cdot 9$ $83^{\circ} 35 \cdot 8^{\prime}$

I64 $55^{\prime} \quad 983.0816$ $\begin{array}{ll}165^{\circ} & 03^{\prime} \quad 983.0855\end{array}$ I65 I I' 983.0883

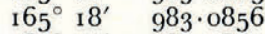
$165^{\circ} 25^{\prime} \quad 983.0834$ I $65^{\circ} 3 \mathrm{O}^{\prime} \quad 983 \cdot 084 \mathrm{I}$ $\begin{array}{lll}165^{\circ} & 3^{\prime} \quad 983.0842\end{array}$ ${ }_{165} 65^{\prime} \quad 983.0836$ I $65^{\circ} 45^{\prime} \quad 983.0882$ $165^{\circ} 55^{\prime} \quad 983.0889$ $166^{\circ} \mathrm{O5}^{\prime} \quad 983.0893$ $166^{\circ}$ Iо $^{\prime} \quad 983.0890$ I $67^{\circ}$ I $7^{\prime} \quad 983 \cdot$ I I06 $I^{168^{\circ}} 4 \mathrm{I}^{\prime} \quad 983 \cdot \mathrm{I} 099$ $169^{\circ} \mathrm{O}^{\prime} \quad 983.1129$ I69 $36^{\circ} \quad 983.1149$ $169^{\circ} 5^{\prime} \quad 983.1113$ $170^{\circ} 35^{\prime} \quad 983.1108$ $171^{\circ} 13^{\prime} \quad 983.1125$ $171^{\circ} 58^{\prime} \quad 983.119^{2}$ $172^{\circ} 32^{\prime} \quad 983 \cdot 1212$ $173^{\circ} 45^{\prime} \quad 983.1216$ $174^{\circ} 24^{\prime} \quad 983.1259$ $174^{\circ} 54^{\prime} \quad 983.1275$ $172^{\circ} 08^{\prime}$

$983 \cdot 0769$

$83^{\circ} 40 \cdot \mathrm{I}^{\prime}$

$83^{\circ} 39 \cdot 3^{\prime}$

$83^{\circ} 3^{8} \cdot 3^{\prime}$

$83^{\circ} 37 \cdot \mathrm{I}^{\prime}$

$83^{\circ} 36 \cdot 7^{\prime}$

$83^{\circ} 36 \cdot \mathrm{I}^{\prime}$

$83^{\circ} 35 \cdot 5^{\prime}$

$83^{\circ} 35 \cdot 2^{\prime}$

$83^{\circ} 34 \cdot 2^{\prime}$

$83^{\circ} 33 \cdot 2^{\prime}$

$83^{\circ} 33 \cdot 1^{\prime}$

$83^{\circ} 3^{2} \cdot 8^{\prime}$

$83^{\circ} 32 \cdot 5^{\prime}$

$83^{\circ} 3 I^{\prime} \cdot I^{\prime}$

$172^{\circ} 29^{\prime}$

$172^{\circ} 27^{\prime}$

$172^{\circ} 26^{\prime}$

$172^{\circ} 21^{\prime}$

$172^{\circ} 13^{\prime}$

$172^{\circ} \mathrm{O} 4$

$171^{\circ} 56^{\prime}$

$171^{\circ} 59^{\prime}$

$171^{\circ} 54^{\prime}$
$171^{\circ} 4^{\prime}$

I $71^{\circ} 38^{\prime}$

$171^{\circ} 30^{\prime}$

$171^{\circ} 53^{\prime}$

$17 \mathrm{I}^{\circ} 3 \mathrm{O}^{\prime}$

983.0859

$983 \cdot 084$ I

983.0958

$983 \cdot 0867$

$983.079^{\circ}$

$983.075^{2}$

$983 \cdot 0659$

$983 \cdot 0679$

983.0700

983.0755

983.0773

983.0839

983.0874

$983 \cdot 1305$

$\begin{array}{llll}6 \text { I } & 83^{\circ} 34 \cdot 0^{\prime} & 172^{\circ} 23^{\prime} & 983 \cdot 088 \text { I }\end{array}$

$6283^{\circ} 32 \cdot 6^{\prime}$

$6383^{\circ} \mathrm{II}^{\mathrm{I}} \mathrm{I}^{\prime}$

$64 \quad 83^{\circ} 29 \cdot 9^{\prime}$

$65 \quad 83^{\circ} 28 \cdot 5$

$66 \quad 83^{\circ} 27 \cdot 0$

$6783^{\circ} 25 \cdot \mathrm{I}^{\prime}$

$68 \quad 83^{\circ} 23 \cdot 3^{\prime}$

$172^{\circ} 42^{\prime}$

$173^{\circ} \mathrm{O} 2^{\prime}$

$173^{\circ} 22^{\prime}$

$173^{\circ} 42^{\prime}$

I $74^{\circ} \mathrm{OI}^{\prime}$

$174^{\circ} 17^{\prime}$

I $74^{\circ} 33^{\prime}$

$983 \cdot 0919$

$983 \cdot 1023$

$983 \cdot$ I 104

$983 \cdot$ I 158

$983 \cdot 1223$

$983 \cdot 125 \mathrm{I}$

$983 \cdot 1262$

$69 \mathrm{R} \quad 83^{\circ} 42 \cdot 9^{\prime}$

$172^{\circ} 42^{\prime}$

$983 \cdot$ IOOI

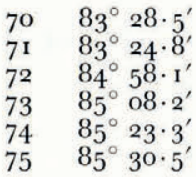

I $76^{\circ} 22^{\prime} \quad 983 \cdot 1339$

$175^{\circ} 37^{\prime} \quad 983.1305$

I $58^{\circ} 52^{\prime} \mathrm{W} .983 \cdot \mathrm{I} 237$

I $55^{\circ} 26^{\prime} \quad 983 \cdot$ I I 78

$\mathrm{I}_{5} \mathrm{I}^{\circ} 4 \mathrm{I}^{\prime} \quad 983 \cdot \mathrm{IO} O$

$\mathrm{I}^{1} \mathrm{I}^{\circ} \mathrm{I}^{\prime} \quad 983 \cdot 1028$

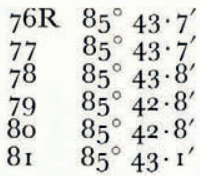

$152^{\circ} \mathrm{O} 4$

$152^{\circ} \mathrm{O} 4^{\prime}$

$152^{\circ} 31^{\prime}$

${ }^{1} 5^{\circ} 23^{\prime}$

I $52^{\circ} \mathrm{I} \mathrm{I}^{\prime}$

$152^{\circ} 06^{\prime}$
$982 \cdot 9906$

$982 \cdot 9890$

$982 \cdot 9042$

$982 \cdot 935^{\mathrm{I}}$

$982 \cdot 9569$

$982 \cdot 9708$
Terrain-

corrected

Free-air Terrain free-air anomaly correction anomaly m. mgal mgal mgal

$80 \quad-21 \cdot 2$

8 o $-16 \cdot 7$

$80-38 \cdot 1$

$78-\mathrm{I} 6 \cdot \mathrm{I}$

$\begin{array}{ll}78 & -17 \cdot 7\end{array}$

$70-18 \cdot 9$

$\begin{array}{ll}72 & -17 \cdot 5\end{array}$

$73-17 \cdot 6$

$5 \mathrm{I}-19.9$

$46-20 \cdot 8$

$50-19.4$

$53-18 \cdot 8$

$44-5 \cdot 5$

$53-8 \cdot 2$

$48-8 \cdot 6$

$44-10 \cdot 1$

$44-15.0$

$46-16 \cdot 7$

$\begin{array}{ll}53 & -14.5 \\ 56 & -8.8\end{array}$

$55-8.6$

$62-8 \cdot 2$

$56-7 \cdot 3$

$57-6 \cdot 5$

I

\begin{tabular}{|c|c|c|c|}
\hline 89 & $-44 \cdot 7$ & 0 & -45 \\
\hline 85 & $-47 \cdot 5$ & o & -48 \\
\hline 61 & $-42 \cdot 9$ & 0 & -43 \\
\hline 81 & $-45 \cdot 4$ & o & -4 \\
\hline 93 & $-49 \cdot 6$ & o & -5 \\
\hline IOI & $-50 \cdot 3$ & o & \\
\hline I I I & $-56 \cdot 4$ & o & -50 \\
\hline 107 & $-55 \cdot 6$ & & \\
\hline 104 & $-54 \cdot \mathrm{I}$ & 0 & -5 \\
\hline IOI & $-49 \cdot \mathrm{I}$ & 0 & -4 \\
\hline 100 & $-47 \cdot 7$ & o & -47 \\
\hline 93 & $-43 \cdot 0$ & o & \\
\hline 108 & $-34 \cdot 9$ & o & -30 \\
\hline 86 & $+\mathrm{I} \cdot 9$ & o & + \\
\hline
\end{tabular}

$90-40 \cdot 2$

$87-36 \cdot 9$

$77-29 \cdot 0$

$71-22 \cdot 4$

$70-16 \cdot 8$

$56-\mathrm{I} 4 \cdot \mathrm{I}$

$60 \quad-9 \cdot 4$

262

$+21 \cdot 6$

o

$+22$

$5^{\mathrm{I}}-4 \cdot 6$

$58-4.6$

I $5-30.6$

$135-37 \cdot 0$

\begin{tabular}{l}
$290+2.8$ \\
\hline
\end{tabular}

$640+4 \cdot 3+9+5$

$643-5 \cdot 0$

$\begin{array}{llll}685 & -76 \cdot 9 & +2 & -75\end{array}$

$633-6 \mathrm{I} \cdot 9+3 \quad-59$

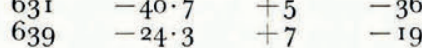




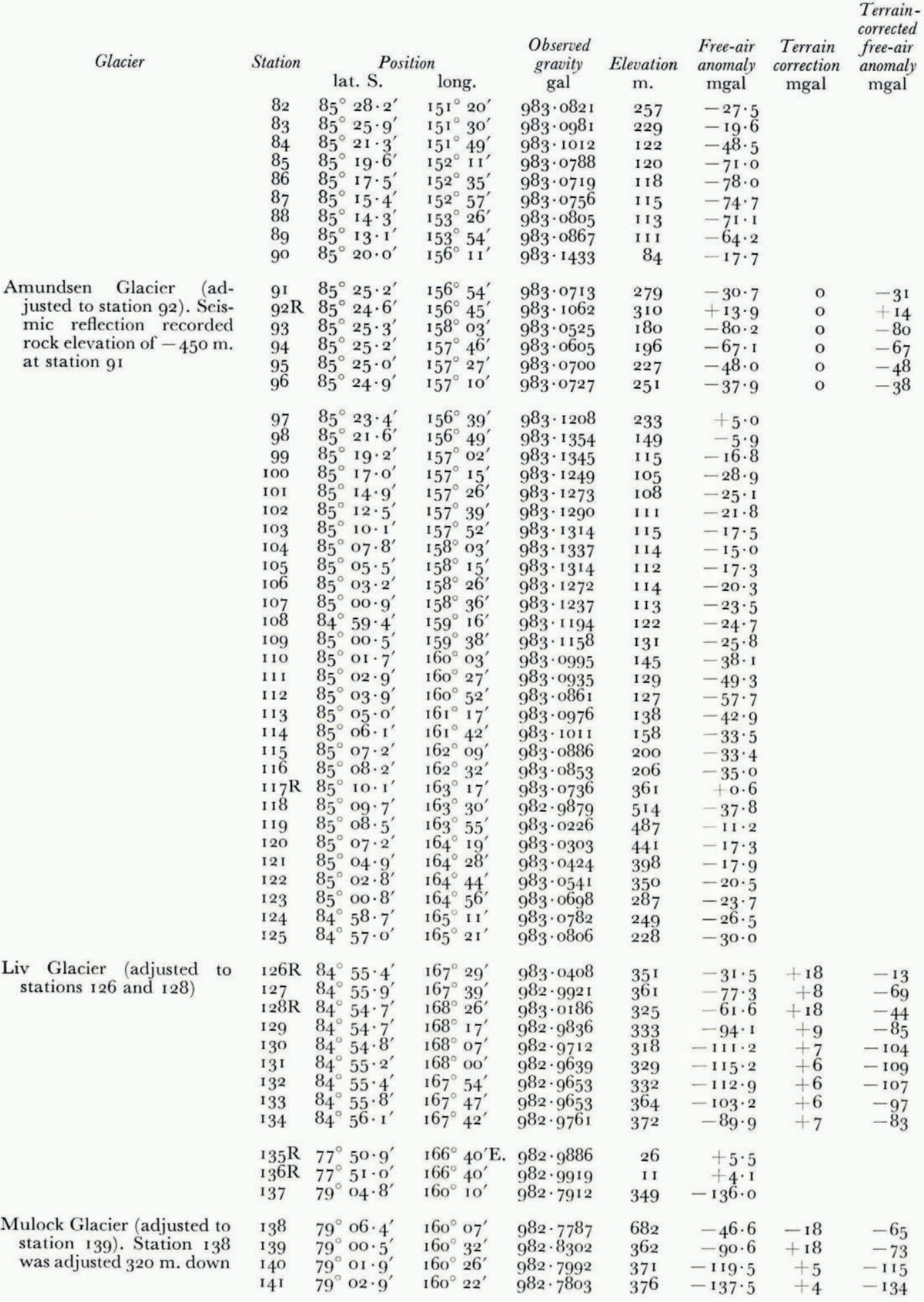


Terraincorrected

Observed Free-air Terrain free-air gravity Elevation anomaly correction anomaly Glacier Station Position lat. S. long. gal $\mathrm{m}$. mgal mgal mgal

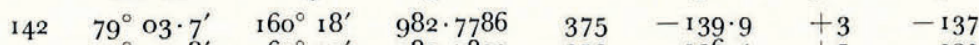

$143 \quad 79^{\circ} \mathrm{O4} \cdot 8^{\prime} \quad 160^{\circ} 13^{\prime} \quad 982.7899 \quad 35^{2}-136.4 \quad+5 \quad-131$

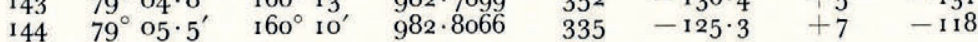

Gravity Values: 1958-59 “Little America V"-Victoria Land Traverse

Skelton Glacier

\begin{tabular}{|c|c|}
\hline $6 \mathrm{r} .0$ & $79^{\circ} \mathrm{oo} \cdot \mathrm{o}^{\prime}$ \\
\hline 6i. & $79^{\circ} \mathrm{oo} \cdot 6^{\prime}$ \\
\hline $6 \mathrm{I} \cdot 2$ & $79^{\circ}$ or $\cdot 2^{\prime}$ \\
\hline I. 3 & $78^{\circ} 59 \cdot 2^{\prime}$ \\
\hline I. 4 & $78^{\circ} 5^{8} \cdot 5^{\prime}$ \\
\hline I . & $78^{\circ} 57 \cdot 8^{\prime}$ \\
\hline $1 \cdot 6$ & $\begin{array}{l}78^{\circ} 5 \\
78^{\circ} 5\end{array}$ \\
\hline & $79^{\circ}$ OI $\cdot 7^{\prime}$ \\
\hline
\end{tabular}

$982 \cdot 9368$

$982 \cdot 9476$

$982 \cdot 9609$

$982 \cdot 9308$

982.9307

982.9347

$982 \cdot 95^{28}$

$982 \cdot 9783$

$982 \cdot 9733$

$\begin{array}{ll}84 & -69 \cdot 4 \\ 71 & -63 \cdot 1 \\ 70 & -50 \cdot 4 \\ 84 & -75 \cdot 0 \\ 80 & -75 \cdot 9 \\ 78 & -72 \cdot 2 \\ 76 & -54 \cdot 3 \\ 72 & -29 \cdot 7 \\ 66 & -39 \cdot 5\end{array}$

-69
-63
-50
-75
-76
-72
-54
-30
-40 